\title{
THE LAW OF ONLINE ZAKAT BASED ON THE APPLICATION PROVIDING EASINESS IN TRANSACTION OF ZAKAT PAYMENT
}

\author{
Sari Utami \\ Lecturer at IAIN Bone \\ Email: sary_utm@yahoo.co.id
}

\begin{abstract}
The importance of zakat distribution in the digital age increasingly shows the existence and urgency of digitalization in all aspects. The purpose of zakat distribution online will facilitate muzakki effectively and efficiently in terms of activities and time in distributing zakat evenly and thoroughly to break the poverty chain, and improve social and economic welfare of the community without having to distinguish between the rich and poor, because behind the distribution of zakat funds is the rights of those who are entitled to receive it (mustahik). This research focused on qualitative research using a descriptive analysis technique which is to conduct an analysis by describing, describing, explaining about paying zakat online in Islamic law. In Islamic view, zakat which is done online is permissible because one of the reasons is that it is only different in form of distribution, namely the transition from manual to automatic. From those who usually come to the institution to pay directly but this time only by accessing and transferring. However, it still does not abandon the terms or conditions in issuing or distributing zakat. Distribution of zakat online is not a problem in terms of Islamic law, because its distribution will facilitate muzakki or Muslims who have an obligation to pay zakat. A muzakki can distribute his zakat online is legal and not a problem legally. Special institutions that are given the mandate in the distribution of zakat will be managed because it is deposited from muzakki which is distributed online and must be in accordance with the principles in sharia provisions. So that the obligation to fulfill or pay zakat continues to be carried out in order to share with others who are entitled to need throughout Indonesia.
\end{abstract}

Pentingnya penyaluran zakat di era digital semakin menunjukkan eksistensi dan urgensi digitalisasi pada semua aspek. Tujuan dari penyaluran zakat secara online ini akan mempermudah muzakki secara efektif dan efisien dari segi kegiatan dan waktu dalam menyalurkan ataupun mendistribusikan zakatnya secara merata dan menyeluruh untuk memutuskan mata rantai kemiskinan, dan meningkatkan kesejahteraan sosial serta ekonomi masyarakat tanpa harus membedakan antara golongan kaya maupun miskin, karena dibalik penyaluran dana zakat tersebut terdapa hak-hak orang yang berhak menerimanya (mustahik). Penelitian ini berfokus pada penelitian kualititatif menggunakan suatu teknik analisis deskriptif yakni 
mengadakan analisa dengan menggambarkan, memaparkan, menjelaskan tentang pembayaran zakat secara online dalam hukum Islam. Dalam pandangan Islam, zakat yang dilakukan secara online ini diperbolehkan karena salah satu alasannya ialah hanya berbeda bentuk penyalurannya saja yaitu peralihan sistem dari manual ke otomatis. Dari yang biasanya datang ke lembaga langsung tetapi kali ini hanya dengan mengakses dan mentransfer. Namun, tetap tidak meninggalkan syarat-syarat ataupun ketentuan-ketentuan dalam mengeluarkan ataupun menyalurkan zakat. Penyaluran zakat secara online bukan suatu permaslahan dari segi hukum Islam, karena penyalurannya akan mempermudah muzakki atau umat muslim yang memiliki kewajiban untuk mengeluarkan zakat. Seorang muzakki dapat menyalurkan zakatnya secara online itu sah saja dan tidak jadi masalah secara hukum. Lembaga khusus yang diberi amanah dalam penyaluran zakat akan dikelolah karena merupakan titipan dari muzakki yang disalurkan secara online dan harus sesuai dengan prinsip dalam ketentuan syariah. Sehingga kewajiban dalam menunaikan atau membayar zakat tetap terlaksana demi berbagi pada sesama yang berhak membutuhkan di seluruh Indonesia.

Keywords: Easiness; Islamic Law; Online; Zakat.

\section{INTRODUCTION}

Technological advances are growing rapidly, public knowledge about online transactions is also developing to facilitate the process of conducting a transaction. Like the zakat transaction, about the object that must be paid zakat. All things can be accessed through online using application features that have been made by various e-commerce companies to access zakat online. So, this online zakat is facilitated by companies that overshadow various e-commerce applications. Indonesia has an institution that has obligations and responsibilities in managing and distributing zakat. In accordance with Presidential Decree Number 8 of 2011 the establishment of the BAZNAS institution, commonly called the National Amil Zakat Agency, has national duties and responsibilities on everything mandated by muzakki to distribute their zakat equally to the mustahik who has the right to receive it. Zakat according to Islamic law is a name of a certain nature and the taking of property or something to be distributed or given to mustahik or people who are entitled to receive it. ${ }^{1}$

The development of information technology in the digital era is fairly fast as well as the level of development of the Islamic religion from year to year. Information technology makes it easier for the public to conduct an online

${ }^{1}$ Regita Cahya Gumilang, Tinjauan Hukum Islam terhadap Keabsahan Pembayaran Zakat yang dilakukan Secara Online yang Berafilisiasi dengan BAZNAS Menurut Imam Syafi' i, Dinamika: Jurnal Ilmiah Ilmu Hukum, Volume 26, Number 7 February 2020, p. 929-939, p. 930. 
transaction making everything more effective and efficient, online transactions such as buying and selling and distributing goods online will simplify and implement a high level of trust and responsibility system as desired. Conformity between convenience with aspects of Islamic law applicable in this digital age will provide a change in the scope of Muslims to do everything that is in accordance with the order of life in carrying out its obligations to worship, share and do good deed (muamalah). ${ }^{2}$

The specificity in the style of an Islamic pillar in which zakat is worship which has two dimensions. In addition to having a social dimension, zakat has an economic dimension which is certainly very important in realizing the welfare of the people. This makes zakat a topic that continues to be studied by experts, in order to realize a social justice in people's lives. Muzakki in distributing zakat to those entitled to receive namely mustahik has a goal not only for worldly interests but also for the afterlife. The world goal that is intended for the benefit of society as a whole, so that there is no difference between the rich and the poor because of the distribution of alms evenly, the growth of social nature to always share with people of different economic groups will increase a full awareness of the responsibilities and welfare together. ${ }^{3}$

The jurists (fuqaha), experts and scholars, from the beginning of Islam to the contemporary period, continued to do in-depth research to study the various socioeconomic aspects of zakat. ${ }^{4}$ With the implementation of targeted zakat, disparity, and gaps that are increasingly felt in the community, will be slowly eliminated. Because zakat conceptually is the main instrument to erase economic inequality and become a stimulus for economic activity by distributing and leveling purchasing power in society. ${ }^{5}$ Widyawati described that the problems of Islamic philanthropy, including zakat and waqf are potentially economical institutions. ${ }^{6}$

The development of technology today makes people seem to be dependent on it in carrying out their daily activities. Internet technology makes it easy to provide access to comfort and services for the public in making transactions. Both

\footnotetext{
${ }^{2}$ Al-Imam Kamal Al-Din Ibn Abd Al-Rahid Al-Sirasi Ibn Al-Humam, SyarḥFatḥal-Qadir, Volume 6 (Beirut: Daral-Kutub al-Ilmiyyah, Tanpa Tahun), p.209.

${ }^{3}$ Irnawati Rais, Muzakki dan Kriterianya dalam Tinjauan Fikih Zakat, Jurnal Al-Iqtishad: Volume 1, Number 1, January 2009, p. 91-106, p. 95-96.

${ }^{4}$ Shalahuddin AzmiMenimbang Ekonomi Islam-Keuangan Publik, Konsep Perpajakan, dan Peran Bait al-Mal., (Bandung: Penerbit Nuansa, 2015), p. 25

${ }^{5}$ Rahmatina Awaliyah Kasri, Niken Iwani S Putri, Fundraising Strategies to Optimize

Zakat Potential in Indonesia: An Exploratory Qualitative Study. Al-Iqtishad: Jurnal Ilmu Ekonomi Syariah (Journal of Islamic Economics), Volume 10 Number 1 2018,. https://doi.org/10.15408/ aiq.v10i1.6191, pp. 1-24, p.6.

${ }^{6}$ Hamzah, p. (2019). Problematika Pengoptimalan Potensi Wakaf Produktif di Kabupaten Bone. Ekspose: Jurnal Penelitian Hukum dan Pendidikan, 18(1), 741-752.
} 
on a small scale such as interactions between individuals, buying and selling transactions, to large scale at the company and industry level. The positive impact of the use of internet technology is broadly felt. ${ }^{7}$

The industrial revolution 4.0 that was echoed, supported by the national movement Making Indonesia 4.0, increasingly showed the existence and urgency of digitalization in all aspects. No exception in terms of raising funds by philanthropic institutions, including zakat. The mechanism and process of collecting zakat, will shift in the direction of the current development, through the use of online media. This shift has begun to be carried out by several zakat management organizations by cooperating with e-commerce sites in an effort to socialize and collect zakat. ${ }^{8}$ In addition, in its deepest dimensions, zakat has the role of social change in society. The funds of the people collected from zakat can be used to finance empowerment programs and vital social change. ${ }^{9}$

Electronic Commerce provides an offer for the ease of doing any transaction in the economic, social and political fields. The scope of the business transactions provided is so broad that several social institutions do a collaboration to facilitate their transactions, such as the processing and distribution of zakat in Indonesia. This official institution formed nationally or commonly called BAZNAS makes it easy for muzakki who want to distribute or pay an obligation of zakat by cooperating with several related parties for the convenience of making online transactions. Not only payment of zakat, but also alms, infaq and endowments are also made online for the sake of smooth and easy transaction by cooperating with several other zakat institutions. ${ }^{10}$

The current digital era makes it easier for people like muzakki to conduct online transaction systems in paying and distributing zakat to mustahik, which has two ways of payment such as: first, the stage of payment and distribution of zakat online easily via smartphones (e-commerce and crowd funding) or through ATMs with the help of applications that work together with processing institutions and the distribution of zakat, and both direct or regular distribution such as making

\footnotetext{
${ }^{7}$ Dirk Lewandowski, Users' Understanding of Search Engine Advertisements. Journal of Information Science Theory and Practice, 5(4) 2017, p. 6-25. https://doi.org/10.1633/JISTaP.2017.5.4.1, p. 12.

${ }^{8}$ Nely Rahmawati Zaimah, Analisis Progresif Skema Fundraising Wakaf dengan Pemanfaatan E-Commerce di Indonesia. Jurnal 'Anil Islam, Volume 10, Number 2, 2017, p. 285316, p. 259.

${ }^{9}$ Ahmad Faisal, Pergumulan Kultur dan Struktur dalam Manajemen Zakat di Pohuwato Gorontalo. Al-Bayyinah, 2019, 3.2: 146-165.

${ }^{10}$ Khairul Rijal, dan Nilawati, Potensi Pembayaran Zakat Secara Online Dan Offline Serta Realisasi Dana Zakat Indonesia, I-Economics: A Research Journal on Islamic Economics, ISSN 2548-5601, e-ISSN 2548-561X, Vol. 5. No 2. December 2019, p. 116-131, p. 118.
} 
payments directly to the processing and distribution institutions of zakat, and there are offers given by processors to pick up the ball to the field (the institution who immediately came to the house muzakki took the zakat funds). Distribution of zakat conducted by muzakki is considered faster and more effective because it is online rather than through direct. ${ }^{11}$ According to the terms and pillars of zakat in a review of Islamic law derived from various thoughts of prominent figures and scholars of jurisprudence who have discussed zakat and researchers want to explain about the clarity about online zakat according to Islamic law to the public so they can understand correctly the importance of paying zakat.

\section{METHODOLOGY}

This research is a qualitative research, where the approach used in this study is the literature approach. Some articles compiled related to research are taken from several literary sources including scientific journals, several books, and related articles published in online media. In addition, data collected from statements of practitioners in the field of zakat management were published in various media. This research analysis technique uses descriptive analysis method, which is to conduct analysis by describing, describing and explaining zakat payment online in Islamic law. This research can be a source of knowledge and knowledge, references and references in learning Islamic law for those who want to get involved in learning and knowing how to extract Islamic law regarding zakat online. As well as with various opinions of contemporary figh figures as well as accurate arguments are part of one of the laws given by the scholars in validating the law and its application to fit the forms outlined in Islamic law.

\section{DISCUSSION}

\section{A. Basic Concept of Zakat}

Understanding of zakat as stipulated in Law Number 23 of 2011 is an obligation that must be paid by a Muslim who is commonly called muzakki or an organization to distribute it to mustahik (some groups that are entitled to receive it) in accordance with the provisions of Islamic law. The purpose in distributing and giving alms to the mustahik is to avoid the difference between the upper and lower classes, improve social welfare in terms of the economy and eliminate poverty lines a little for the economic prosperity of the ummah. ${ }^{12}$ The purpose of zakat

\footnotetext{
${ }^{11}$ Kurniawati, Kedermawanan Kaum Muslimin : Potensi Dan Realita Zakat Masyarakat Di Indonesia. (Jakarta: Piramedia (PIRAC)), p. 22.

${ }^{12}$ Republik Indonesia, "Undang-Undang RI Number 23 Tahun 2011 Tentang Pengelolaan Zakat."
} 
distribution as stipulated in PSAK Number 109 that is, payment for a very pure purpose for musakki who fulfill their obligations for the needs and welfare of the mustahik together. With this goal, it gives a trust to zakat processors because the responsibility for zakat funds to be distributed must be properly managed properly, so that the goals of muzakki are achieved and in accordance with Islamic law. ${ }^{13}$

Discussion on the management of zakat as stipulated in Law Number 23 of 2011 is an arrangement, grouping, planning, and implementation of funds that have been collected by muzakki to be distributed to mustahik who are entitled to receive it. Nationally, there are several institutions that are given the mandate and responsibility to carry out the collection, management and distribution of zakat funds from musakki. This zakat management agency carries out its duties with authority based on official legal entities such as BAZNAS, LAZ and UPZ so that it can be trusted by the public in the distribution of zakat funds. ${ }^{14}$

Every person included in the category of muzaki is required to pay zakat as one of his obligations, if the muzakki has reached the limit of possession of his property then it must be given to the needy and poor or other mustahik groups, as zakat is also believed to be a compulsory worship. ${ }^{15}$ When viewed from a number of verses of the Qur'an revealed in Mecca that talk about zakat, found statements about zakat mentioned in the verse are in the form of news sentences or ordinary statements. ${ }^{16}$ This condition illustrates the condition of the Muslim community at that time, about the importance of understanding the distribution of zakat because it is contained in the most important and important pillars of Islam for all who carry out zakat will be praised and rewarded. Instead, there will be insults and torment for those who are reluctant to do it. Zakat is a differentiator between Islam and disbelief, between faith and hypocrisy, also between piety and lawlessness. ${ }^{17}$

Muzakki in making payments or distribution of zakat can be done directly or online to zakat management institutions that work together with several other online transaction companies with the aim of facilitating the transaction process, even manually or directly hand over to institutions that have been given the mandate and responsibility in distributing zakat to the mustahik. Some of the

\footnotetext{
${ }^{13}$ Ikatan Akuntan Indonesia, Pernyataan Standar Akuntansi Keuangan Number 109, (Jakarta: IAI, 2011)

Zakat."

${ }^{14}$ Republik Indonesia, "Undang-Undang RI Number 23 Tahun 2011 Tentang Pengelolaan

${ }^{15}$ Abdurrahman Al-Jaziri, Kitab Al-Fiqh 'Ala Al-Madzahib Al-Arba'ah, (Kairo: Dar al-Jauzy, 2014), p. 43.

${ }^{16}$ Yusuf Al-Qardhawi, Hukum Zakat (Terj.), (Bogor: PT. Pustaka Literasi Antarnusa, 2011), p.85.

${ }^{17}$ Yusuf Al-Qardhawi, Shadaqah, Cara Islam Mengentaskan Kemiskinan, (Bandung: PT. Remaja Rosdakarya, 2010), p. 115.
} 
convenience provided by muzakki to make payment transactions or distribution of zakat with automatic payment of net income obtained or directly using smartprhone with offer vitur or zakat payment applications that exist automatically and online so it is very easy for muzakki to perform his obligations to pay zakat. The ease in distributing zakat effectively and efficiently will facilitate zakat processing institutions in distributing zakat to mustahik who has the right to receive it. ${ }^{18}$

\section{B. Legal Basis, Mandatory and Legitimate Requirements of Payment of Zakat}

Distribution and management of zakat has a basis that cannot be underestimated because it is guided by the Holy Qur'an and Hadith. The discussion on zakat also has a legal basis so that it gives its own confidence in implementing it based on the existing pillars of Islam. The explanation of zakat in the Holy Qur'an is so specific and comprehensive that the process of implementation up to its distribution can be understood from various aspects and objectives. Distribution of zakat conducted by muzakki has a very noble purpose, namely for the benefit of the economy and welfare of the Ummah.

Mandatory conditions that must be fulfilled by each muzakki are as follows: ${ }^{19}$ First, Muslims, that paying zakat is obligatory for every Muslim; secondly, independence, that is, a slave is not obliged to pay the obligation to pay zakat, so they must be free from the slavery of their master; thirdly, the assets owned have reached Nisab where the amount or weight of the assets owned is obligatory to issue zakat; fourth, the assets owned have reached the haul, where the period of one satun of the amount of assets owned; fifth, the assets owned are private property, not assets from other people's loans or assets that have other cases.

The two legal requirements for the implementation of zakat are as follows: ${ }^{20}$ First, intention, where everything originates from intention, which is a condition for carrying out a worship and issuing or distributing zakat; Secondly, Tamlik, namely the implementation of the legal requirements for zakat, namely zakat assets handed over to mustahik, for those who are entitled to receive it directly or through the zakat management institution.

${ }^{18}$ Khairul Rijal, Analysis of Online Portal and E-Payment Application Usage: A Case Study of BAZNAS Indonesia. International Conference of Zakat. Proceeding $2^{\text {nd }} I C O N Z$ Internasional Conference Of Zakat_BAZNAS. ISSN: 2655-6251, DOI: https://doi.org/10.37706/iconz, Published: 2019-0214 , p. 43-51, p. 44.

${ }^{19}$ Syakir Jamaluddin, Kuliah Fiqih Ibadah, (Yogyakarta: Surya Sarana Grafika, 2010), p. 199.

${ }^{20}$ Elsi Kartika, Pedoman Pengelolaan Zakat (Semarang: UNNES Press, 2006), p. 39-40 


\section{Management of Zakat in the Position of Islamic Law in Indonesia}

The development of the digital era greatly influenced the position of the Islamic community in occupying a very complex position as a citizen in accordance with Islamic law, the community did not have the readiness for current technological developments. Even sometimes change causes a conflict because of the many changes that are not in accordance with the mind of each person. Islamic law is present to answer all the problems that exist in the current Muslim society gap. Difficulties or existing gaps will be overcome by discussions that cry out on existing problems. ${ }^{21}$

Distribution of zakat by muzakki is the distribution of wealth to be distributed to mustahik equally, in other words, a muzakki gives assets that have reached the haul and nasabnya to be distributed to mustahik who has the right to receive it evenly and thoroughly distribution. Distribution or transfer of zakat funds can be done directly by muzakki to a trusted institution according to him or directly using online transactions. The point is the distribution of zakat is done with the aim of social welfare of the interests of many people with one of the goals of cleaning up the assets owned by muzakki without any social disparity between the rich and poor. With the expectation of the managers and distributors of zakat funds from muzakki to mustahik can be distributed in accordance with Islamic law and legal requirements. ${ }^{22}$

The purpose of legislation on Islamic law is a regulation that already is in the laws of a country. The division of legislation on Islamic law is important in the development of joint decision provisions carried out by the ulamas for a common goal in Islamic law. Muamalah group in this case is a forum in a joint decision which is then negotiated and agreed upon. Supporting the success of zakat distribution and management as a whole is influenced by three aspects, as follows: First, the aspect of substance, aspects which together relate to existing legal norms, both Ilsma legal norms or legal norms based on applicable legislation; Second, structural aspects, law enforcement together in managing zakat in a professional manner so that there are no irregularities in zakat distribution. So that the zakat funds given by muzakki to mustahik are distributed to eight groups who are entitled to receive them. Third, community legal awareness, community awareness that acts as muzakki is very necessary in the distribution and awareness of the importance of paying zakat, the importance of zakat for the life of mustahik in the economic

${ }^{21}$ A. A. Miftah, Teori Diyani dan Qadha'i dalam Pembangunan Hukum Islam Kontemporer, Innovation journal of religious innovation studies, Vol. 9, Number 2, 2010, p. 2.

${ }^{22}$ John L. Esposito, Ensiklopedi Oxford: Dunia Islam Modern [terj.] Eva Y.N. et al., (Bandung: Mizan, 2001), p. 24. 
distribution of the middle to lower classes and breaking the existing poverty chain. Zakat management institutions have a legal basis in the distribution process because it is a mandate and responsibility for processing institutions to be directly forwarded by mustahik. ${ }^{23}$

\section{Online-Based Zakat Payments According to Islamic Law}

Zakat collection from various sectors is very helpful by applying the current system. Therefore, to answer the challenges of society in the digital era as it is today, with their digital lifestyle, zakat institutions need to transform using the latest technology, in order to collect zakat from muzaki, and of course it will provide convenience for muzaki in paying their zakat to the institution zakat. Islam as a universal religion, is very open to the dynamics of the development of human civilization. No exception, in terms of technological developments in the economic and financial fields. So zakat, as an amaaliyah worship, must still be in the corridor of sharia compliance even though applying technology in its application. ${ }^{24}$

The sophistication of technology in the digital era today, in many payment transactions and distribution of zakat has been done online. Can be online by accessing the website via a smartphone or already in a container called e-commerce. When conducting transactions or agreements, it is obligatory to show honesty because there is evidence of mutation or every transaction made. ${ }^{25}$

Zakat can be accessed through the website or via smartphone is the main thing in the online zakat payment process this time. Online zakat is a stage of the implementation of muzakki's obligation to transfer some of his assets that have reached the conditions by using a digital information technology system that has many institutions that work with online e-commerce companies, where muzakki very easily make zakat payment transactions without having to directly pay zakat to zakat institutions. In this BAZNAS amil zakat institution, it provides zakat fitrah and zakat maal services and other types of zakat maal. ${ }^{26}$ Of the various types of zakat,

${ }^{23}$ Aden Rosadi, Amil Zakat Menurut Hukum Islam dan Peraturan Perundang-undangan, Al-Manahij: Jurnal Kajian Hukum Islam, Vol. XI. Number 2, December 2017, p. 189-198, p. 195.

${ }^{24}$ Muhammad Aulia Rachman dan Annisa Nur Salam, The Reinforcement of Zakat Management Trougt Financial Technology Systems, International Journal of Zakat | ISSN: 25482335 | Vol. 3 (1) 2018, p. 57-69, p. 62.

${ }^{25}$ M. Taufik Misranto, (June 2018), Yurispruden: Keselamatan Tenaga Kerja Dalam Perspektif Hak Asasi Manusia (Prespektif Islam, UDHR, dan Hukum Positif), Vol. 1, Number 2, p. 194-205.

${ }^{26}$ Ade Nur Rohim, Optimalisasi Penghimpunan Zakat Melalui Digital Fundraising, AlBalagh: Jurnal Dakwah dan Komunikasi, Vol. 4, Number 1, January - June 2019, p. 59 - 90, DOI: 10.22515/balagh.v4i1.1556, ISSN: 2527-5704 (P) ISSN: 2527-5682, p. 70. 
muzakki can choose which type of zakat will be distributed through the amil institutions chosen to be distributed to mustahik later.

The main factors of paying zakat online: 1) To make efficiency and effectiveness as well as facilitating the payment process, 2) Saving time, 3) Availability of information, which has many explanations and answers to problems and methods of calculating zakat (zakat calculator) provided, 4) The safety factor in conducting online transactions is very important and must be guaranteed at all times. All payment transactions, registrations, questions, and all other related matters must and can be done quickly and easily. Information technology systems play an important role in disseminating information and promoting zakat because the media are important in the process of collecting zakat and the process of disseminating information and payment instruments, by zakat institutions. Zakat institutions or zakat management institutions need to increase the use of technology and the internet in all matters for the benefit of Muslims in fulfilling their duties and obligations as Muslims. ${ }^{27}$

Zakat distributed online is not a problem according to Chairman of the Fatwa Commission of Indonesian Ulema Council (MUI), Hasanuddin A.F. The convenience gained in making online payment transactions is greatly felt by the muzakki. The ease with which zakat is distributed online is not a problem in Islamic law. However, the duties of zakat managers must remain responsible even though zakat funds are paid online, as well as those carried out in accordance with the principles in sharia provisions. The validity of zakat online remains with muzakki, the property that is issued, and mustahiq. Those who belong to the group of muzakki are those who have assets that have reached the nisab and can meet the obligatory zakat criteria. Then, the zakat property is a property that must be issued zakat. And the last is mustahiq or people who are entitled to receive zakat with the existing provisions. ${ }^{28}$

There is an agreement on opinion about the payment of zakat fitrah which is directly given to mustahik must not be in the form of money according to the Maliki, Shafi'i and Hambali schools which come from the historical hadith of Abu Said, where hadith narrated by Musllim Number 985, which discussed about the time of the Prophet Muhammad (pbuh), he distributed zakat fitrah as much as one sha' of food which at that time the food he and his companions consisted of wheat, wine, dates and cheese. The hadith discussed the distribution or payment of zakat

\footnotetext{
${ }^{27}$ Khairul Rijal, Analysis of Online Portal and E-Payment Application Usage: A Case Study of BAZNAS Indonesia.., p. 49-50.

${ }^{28}$ MUI Ingatkan Masyarakat yang Berzakat Online accessed from https://www.republika.co.id/berita/dunia-islam/wakaf/17/06/07/or653i423-muiingatkanmasyarakat-yang-berzakat-online pada tanggal 7-06-2020 at 15:30.
} 
fitrah submitted in the form of food made by the companions of the Prophet (pbuh). Distribution of zakat in the form of food is their habit which is carried out mainly on zakat fitrah so that it reinforces what is discussed in the hadith. And there are also arguments about the payment or distribution of zakat fitrah in terms of certain assets so that payments may not be in the form of these types of assets. Thus, it is not allowed to carry out beyond the allotted time. ${ }^{29}$

Imam Shafi'i said that if it is not permissible to use money in terms of zakat fitrah through any distribution, it means that the alternative to the opinion is to use zakat maal which is actually from wealth or forms of money and so on. However, according to the theories the writer got, online zakat is not a problem as long as the conditions or elements of zakat cannot be abandoned or skipped. Because Islam will not complicate an act of worship if it is carried out seriously and in accordance with established provisions. The community should be time to understand well what has developed. With this online charity, it is very easy and very simple for people who do not have time to come directly to the nearest zakat alms. Just fill in the data and then transfer the amount of money via ATM, internet banking or mobile banking via a smartphone.

Then there is also Zakat Maal in its calculation in the form of payment of zakat originating from valuable assets such as assets, money, gold, shares, as contained in the Al-Qur'an at Surah At-Tawbah verse 103 and contained in the discussion of the Minister of Religion Regulation Number 52/2014 and also opinions expressed by Shaikh Yusuf Qardhawi. So, paying zakat online is legal or valid means it is permissible or legitimate, makes it easy to pay zakat and does not violate the legal terms and conditions of issuing zakat. Because according to Yusuf Al-Qardhawi who follows Imam Syafi'i in Fiqhuzzakat, more or less says that "Someone paying zakat (muzakki) should not say directly to what is given is zakat and is a legal thing" means, according to the opinion Shaykh Yusuf Al-Qardhawi they can distribute their zakat through online through the desired amil zakat institutions or bodies or those that have cooperated with several zakat distribution institutions. The mention of Ijab qabul in paying zakat is not included in the pillars of zakat and legal requirements that have been explained above, where zakat is different from alms, endowments, leases, debt, accounts receivable, pawn and other transactions which must use the qabul consent at the beginning of the transaction. $^{30}$

\footnotetext{
${ }^{29}$ Regita Cahya Gumilang, Tinjauan Hukum Islam terhadap Keabsahan Pembayaran Zakat yang dilakukan Secara Online yang Berafiliasi dengan BAZNAS.., p.934.

${ }^{30}$ Regita Cahya Gumilang, Tinjauan Hukum Islam terhadap Keabsahan Pembayaran Zakat yang dilakukan Secara Online yang Berafiliasi dengan BAZNAS.., p.934-935.
} 
In the view of Islamic law, zakat which is done online is permissible because one of the reasons is that it is only different in form of distribution, namely the transition of the system from manual to automatic. Online zakat payment is considered as one of the factors that can contribute to the increase in zakat payments because of the ease and smoothness of transactions. From those who usually come to zakat management institutions directly but this time only by accessing and transferring via smartphone only in the hands of muzakki can make zakat payment transactions online. However, it still does not leave the legal requirements or provisions in distributing zakat.

\section{CONCLUSION}

The current digital era, makes it easier for people like muzakki to do an online transaction system in paying and distributing zakat to mustahik which has two payment methods such as: first, the stage of payment and distribution of zakat online easily through smartphones (ecommerce and crowd funding) or through an ATM with the help of an application that works in cooperation with the management and distribution of zakat, and second, direct or regular distribution such as making payments directly to the management institution and zakat distribution, and there is an offer given by the manager to pick up the ball to the field (the institution that comes directly to the house of muzakki takes the zakat funds). Distribution of zakat conducted by muzakki is considered faster, more effective and efficient because it is online rather than through direct. Zakat payment made by muzakki online in conducting transactions is not a problem in Islamic law. With this online zakat payment transaction, it is very easy and very simple for people who do not have the time to come directly to the amil zakat management institutions. It only needs filling in the data and then transferring the amount of money via ATM, internet banking or mobile banking via a smartphone.

The validity of zakat online remains with muzakki, the property that is issued, and mustahiq. However, it still does not abandon the terms or conditions in paying or distributing zakat. Zakat payment transactions online according to Islamic law is not a problem. But a convenience to the offer made by muzakki in making zakat payment transactions online. A muzakki can distribute his zakat online is legal and not a problem legally. Where zakat management institutions that have been given the mandate to manage zakat funds from muzakki must be fully responsible because they are deposited funds from muzakki that are paid online which must be in accordance with the principles in sharia provisions. So that our obligation to fulfill or pay zakat will continue to be carried out in order to share with others who have the right to need it throughout Indonesia. This aspect is in accordance with 
the objective of distributing zakat evenly and thoroughly to break the poverty chain, and improve social and economic welfare of the community without having to distinguish between the rich and poor, because behind the distribution of zakat funds there are rights of people entitled to receive them (mustahik).

\section{REFERENCES}

Al-Imam Kamal al-Din Ibn 'Abd al-Rahid al-Sirasi Ibn al-Humam, SyarḥFathalQadīr, Jilid 6 (Beirut: Daral-Kutub al-'Ilmiyyah, without year).

Al-Jaziri, Abdurrahman. Kitab Al-Fiqh 'Ala Al-Madzahib Al-Arba'ah, (Kairo: Dar alJauzy, 2014).

Al-Qardhawi, Yusuf. Hukum Zakat (Terj.), (Bogor: PT. Pustaka Literasi Antarnusa, 2011).

-.m.m.m. Shadaqah, Cara Islam Mengentaskan Kemiskinan, (Bandung: PT. Remaja Rosdakarya, 2010).

Azmi, Shalahuddin. Menimbang Ekonomi Islam-Keuangan Publik, Konsep Perpajakan, dan Peran Bait al-Mal., (Bandung: Penerbit Nuansa, 2015).

Esposito, John L. Ensiklopedi Oxford: Dunia Islam Modern (Translation), Eva Y.N. et al., (Bandung: Mizan, 2001).

Faisal, Ahmad. "PERGUMULAN KULTUR DAN STRUKTUR DALAM MANAJEMEN ZAKAT DI POHUWATO GORONTALO." AlBayyinah 3.2 (2019): 146-165.

Gumilang, Regita Cahya. Tinjauan Hukum Islam terhadap Keabsahan Pembayaran Zakat yang dilakukan Secara Online yang Berafiliasi dengan BAZNAS Menurut Imam Syafi'i, Dinamika: Jurnal Ilmiah Ilmu Hukum, Volume 26, Number 7 February 2020, p. 929-939.

Hamzah, H. (2019). Problematika Pengoptimalan Potensi Wakaf Produktif di Kabupaten Bone. Ekspose: Jurnal Penelitian Hukum dan Pendidikan, 18(1), 741-752.

Ikatan Akuntan Indonesia, Pernyataan Standar Akuntansi Keuangan Nomor 109, (Jakarta: IAI, 2011).

Jamaluddin, Syakir. Kuliah Fiqih Ibadah, (Yogyakarta: Surya Sarana Grafika, 2010).

Kartika, Elsi. Pedoman Pengelolaan Zakat (Semarang: UNNES Press, 2006). 
Kasri, Rahmatina Awaliyah; Niken Iwani S Putri. Fundraising Strategies to Optimize Zakat Potential in Indonesia: An Exploratory Qualitative Study. Al-Iqtishad: Jurnal Ilmu Ekonomi Syariah (Journal of Islamic Economics), Volume 10 Number 1 2018,. https://doi.org/10.15408/aiq.v10i1.6191, p. 1-24.

Kurniawati, Kedermawanan Kaum Muslimin : Potensi Dan Realita Zakat Masyarakat Di Indonesia. (Jakarta: Piramedia (PIRAC)).

Lewandowski, Dirk. Users' Understanding of Search Engine Advertisements. Journal of Information Science Theory and Practice, 5(4) 2017, https://doi.org/10.1633/JISTaP.2017.5.4.1, p. 6-25.

Miftah, A. A. Teori Diyani dan Qadha'i dalam Pembangunan Hukum Islam Kontemporer, Innovation journal of religious innovation studies, Vol. 9, Number. 2, 2010, p. 189-198.

Misranto, M. Taufik. Yurispruden: Keselamatan Tenaga Kerja Dalam Perspektif Hak Asasi Manusia (Prespektif Islam, UDHR, dan Hukum Positif), Vol. 1, Number 2, (June 2018), p. 194-205.

MUI Ingatkan Masyarakat yang Berzakat Online accessed from https://www.republika.co.id/berita/duniaislam/wakaf/17/06/07/or653i423-mui-ingatkanmasyarakat-yang-berzakatonline pada tanggal 20-05-2020 at 15:30.

Rachman, Muhammad Aulia dan Annisa Nur Salam. The Reinforcement of Zakat Management Trougt Financial Technology Systems, International Journal of Zakat | ISSN: 25482335 | Vol. 3 (1) 2018, p. 57-69.

Rais, Irnawati. Muzakki dan Kriterianya dalam Tinjauan Fikih Zakat, Jurnal AlIqtishad: Volume 1, Number 1, January 2009, p. 91-106

Rijal, Khairul. Analysis of Online Portal and E-Payment Application Usage: A Case Study of BAZNAS Indonesia. International Conference of Zakat. Proceeding $2^{\text {nd }}$ ICONZ INTERNASIONAL CONFERENCE OF ZAKAT_BAZNAS. ISSN: 2655-6251, DOI: https://doi.org/10.37706/iconz, Published: 2019 02-14, p. 43-51.

Rijal, Khairul dan Nilawati. Potensi Pembayaran Zakat Secara Online Dan Offline Serta Realisasi Dana Zakat Indonesia, I-Economics: A Research Journal on Islamic Economics, ISSN 2548-5601, e-ISSN 2548-561X, Vol. 5. Number 2. December 2019, p. 116-131.

Rohim, Ade Nur. Optimalisasi Penghimpunan Zakat Melalui Digital Fundraising, Al-Balagh: Jurnal Dakwah dan Komunikasi, Vol. 4, Number 1, January - June 
2019, DOI: 10.22515/balagh.v4i1.1556, ISSN: 2527-5704 (P) ISSN: $2527-$ 5682, p. 59-90.

Rosadi, Aden. Amil Zakat Menurut Hukum Islam dan Peraturan Perundangundangan, Al-Manahij: Jurnal Kajian Hukum Islam, Vol. XI. Number 2, December 2017, p. 189-198.

Republik Indonesia, "Undang-Undang RI Nomor 23 Tahun 2011 Tentang Pengelolaan Zakat."

Zaimah, Nely Rahmawati. Analisis Progresif Skema Fundraising Wakaf dengan Pemanfaatan E-Commerce di Indonesia. Jurnal 'Anil Islam, Volume 10, Number 2, 2017, p. 285-316. 